\title{
NANOPARTICLES ECOTOXICITY ON DAPHNIA MAGNA
}

\author{
Reza KHOSHNOOD *, Neamat JAAFARZADEH **, \\ Shahla JAMILI ***, Parvin FARSHCHI * and Lobat TAGHAVI *
}

\begin{abstract}
* Department of Energy and Environment, Science and Research Branch, Islamic Azad University, Tehran, Iran, Simon Bulivar Boulevard, Daneshgah, IR-1477893855, RezaKhoshnood@gmail.com, taghavi_lobat@yahoo.com, parvinfarshchi@gmail.com

** Ahvaz Jundishapur University of Medical Sciences, Environmental Technologies Research Center, Ahvaz, Iran, IR-61357-15794, n.jaafarzade@yahoo.com

*** Department of Marine Biology, Science and Research Branch, Islamic Azad University, Tehran, Iran, Daneshgah Boulevard, Simon Bulivar Boulevard, IR-1477893855, shahlajamili45@yahoo.com
\end{abstract}

KEYWORDS: acute toxicity, titanium dioxide, copper oxide, zinc oxide.

\section{ABSTRACT}

In recent years, development of nanotechnology as well as the toxicity potential of nanomaterials on the environment has received much attention. In order to assess the potential toxic impact of nanoparticles on aquatic environments, we used three kinds of nanoparticles, including titanium dioxide $\left(\mathrm{TiO}_{2}\right)$, copper oxide $(\mathrm{CuO})$, and zinc oxide $(\mathrm{ZnO})$ on an aquatic model species, Daphnia magna. In fact, Daphnia magna was exposed to different concentrations for $24,48,72$, and $96 \mathrm{~h}$ at $20-25^{\circ} \mathrm{C}$. All the important water quality parameters, such as temperature, $\mathrm{pH}$, and dissolved oxygen (DO) were controlled to meet the standard requirements during the experiment. The $\mathrm{LC}_{50}$ values for $24,48,72$, and $96 \mathrm{~h}$ were estimated statistically using Probit methods. The $\mathrm{LC}_{50} 48 \mathrm{~h}$ values for $\mathrm{TiO}_{2}$, CuO, and $\mathrm{ZnO}$ were 171.88 $\mathrm{mg} / \mathrm{l}, 6.62 \mathrm{mg} / \mathrm{l}$, and $3.23 \mathrm{mg} / \mathrm{l}$, respectively.

ZUSAMMENFASSUNG: Die Ökotoxizität von Nanopartikeln an Daphnia magna.

Die Entwicklung der Nanotechnologie in den letzten Jahren sowie das Toxizitätspotential von Nanomaterial werden in dieser Arbeit behandelt. Um die potentiellen toxischen Einwirkungen von Naopartikeln in aquatischer Umwelt zu ermitteln, wurden drei verschiedene Nanopartikeln von Titan Dioxyd $\left(\mathrm{TiO}_{2}\right)$, Kupferoxyd $(\mathrm{CuO})$ und Zink Oxyd $(\mathrm{ZnO})$ an einer aquatischen Modellart Daphnia magna untersucht. Daphnia magna wurde unterschiedlichen Konzentrationen für 24, 48, 72 und 96 Stunden bei $20-35^{\circ} \mathrm{C}$ ausgesetzt. Sämtliche der Wasserqualitätsparameter wie Temperatur, pH und DO wurden kontrolliert, um die Standardansprüche während des Experiments kennenzulernen. Die LC $_{50}$ Werte für 24, 48, 72 und 96 Stunden wurden statistisch mit Hilfe der Probit Methode geschätzt. Die LC $_{50} 48$ Stunden Werte für $\mathrm{TiO}_{2}$, $\mathrm{CuO}$ und $\mathrm{ZnO}$ betrugen jeweils $171.88 \mathrm{mg} / \mathrm{l}, 6.62 \mathrm{mg} / \mathrm{l}, 3.23 \mathrm{mg} / \mathrm{l}$.

REZUMAT: Ecotoxicitatea nano particulelor la Daphnia magna.

Dezvoltarea nanotehnologiei în ultimii ani şi potentialul de toxicitate a acestora constituie subiectul prezentei lucrari. Pentru a evalua potenţialul impact toxic al nanoparticulelor în mediu acvatic, au fost folosite trei feluri de nanoparticule cum sunt dioxidul de titan $\left(\mathrm{TiO}_{2}\right)$, oxidul de cupru $(\mathrm{CuO})$ şi oxidul de zinc $(\mathrm{ZnO})$, pe o specie-model acvatică, Daphnia magna. Daphnia magna a fost expusă la diferite concentraţii timp de 24, 48, 72 și 96 de ore la $20-35^{\circ} \mathrm{C}$. Parametri de calitate a apei ca: temperatura, $\mathrm{pH}$-ul şi oxigenul dizolvat au fost controlaţi pentru a cunoaşte cerinţele standard în timpul experimentului. Valorile $\mathrm{LC}_{50}$ pentru 24, 48, 72 şi 96 ore au fost estimate statistic cu ajutorul metodei Probit. Valorile de $\mathrm{LC}_{50}$ la 48 de ore pentru $\mathrm{TiO}_{2}$, $\mathrm{CuO}$ și $\mathrm{ZnO}$ au fost de $171.88 \mathrm{mg} / \mathrm{l}, 6.62 \mathrm{mg} / \mathrm{l}$, $3.23 \mathrm{mg} / \mathrm{l}$ la respectivul experiment. 


\section{INTRODUCTION}

In the past decade, there was less concern and attention about nanoparticles (NPs) and nanomaterials (Lovern and Klaper, 2006; Masciangioli and Zhang, 2003). In recent years, however, by finding more evidence about the potential impact of NPs, they have come under scrutiny. It seems that NPs can enter into the aquatic ecosystem as a result of their proposed use in industries (Fabrega et al., 2013).

Daphnia is known as a bio-indicator used by various organizations around the world and is suggested by U.S. Environmental Protection Agency (U.S.EPA) for bioassay test. D. magna can be utilized as an aquatic bio-indicator because this species is able to filter an average of $16.6 \mathrm{ml} / \mathrm{h}$ (McMahon and Rigler, 1965), and consequently has a great potential to be affected by pollutant particulates such as NPs. Nanoparticles have the capability to be absorbed during filtration, hence have an impact on feeding ability. Because $D$. magna has a key role in the aquatic food chain between the algae and fish which feed on them, it is necessary to find out the toxic response and effect of NPs on D. magna (Lovern and Klaper, 2006).

Several studies performed on the eco-toxicity of $\mathrm{TiO}_{2}$ NPs have already showed that these NPs have low toxicity (Ozkan et al., 2015; Johari and Asghari, 2015; Zhu et al., 2010). In particular, Heinlaan et al. (2008) studied the toxicity of NPs, such as $\mathrm{ZnO}, \mathrm{CuO}$, and $\mathrm{TiO}_{2}$ on Vibrio fischeri, Daphnia magna, and Thamnocephalus platypus, and demonstrated that $\mathrm{TiO}_{2}$ NPs did not have any toxicity in low concentrations (below $20 \mathrm{mg} / \mathrm{l}$ ). Similarly, Griffitt et al. (2008) could not find any evidence for $\mathrm{TiO}_{2}$ toxicity in standard eco-toxicological tests with zebra fish, Daphnia, and algae.

Considering this fact that $D$. magna has a key role in the aquatic food chain, studying the toxicity of NPs on this organism would offer important insights into a broad impact of NPs in the aquatic environment.

The main aim of this study was to assess the potential toxic effects of NPs on freshwater environments. For this purpose, three different NPs including titanium dioxide $\left(\mathrm{TiO}_{2}\right)$, copper oxide $(\mathrm{CuO})$, and zinc oxide $(\mathrm{ZnO})$ were used on an aquatic model species, Daphnia magna.

\section{MATERIAL AND METHODS}

Zinc oxide $(\mathrm{ZnO})$, titanium dioxide $\left(\mathrm{TiO}_{2}\right)$, and copper oxide $(\mathrm{CuO})$ nanoparticles were purchased from U.S. Research Nanomaterial's Inc., Houston, TX, USA. The physical properties of NPs are listed in table 1. The NPs stock solutions were prepared by suspending selected NPs powders in deionized water at a stock concentration of $20 \%(\mathrm{w} / \mathrm{v})$. Vortexes for $20 \mathrm{~s}$ at $2000 \mathrm{rpm}$ were used for homogenizing the suspension (Ozkan et al., 2015; Ates et al., 2013). The stock suspension was transferred immediately into the $500 \mathrm{ml}$ beaker which contained D. magna.

Table 1: Size distribution and other characteristics of nanoparticles.

\begin{tabular}{|c|c|c|c|c|}
\hline Nano Particles & APS & SSA & Purity & Color \\
\hline $\mathrm{CuO}$ & $40 \mathrm{~nm}$ & $\sim 20 \mathrm{~m}^{2} / \mathrm{g}$ & $99 \%$ & black \\
\hline $\mathrm{ZnO}$ & $10-30 \mathrm{~nm}$ & $20-60 \mathrm{~m}^{2} / \mathrm{g}$ & $+99 \%$ & milky white \\
\hline $\mathrm{TiO}_{2}$ & $20 \mathrm{~nm}$ & $10-45 \mathrm{~m}^{2} / \mathrm{g}$ & $+99 \%$ & white \\
\hline
\end{tabular}

SSA: Specific Surface Area, APS: Average Particle Size. 
Daphnia magna was obtained from the health faculty of Shahid Beheshti University. Daphnia magna was maintained at a constant temperature $\left(22 \pm 2^{\circ} \mathrm{C}\right)$ with natural light-dark cycle.

Some of the water quality parameters, including $\mathrm{pH}$, DO, EC, and temperature were measured in each test during the experiment. The temperature was measured using a digital thermometer. The solution $\mathrm{pH}$ was measured using a ColeParmer Model 5398-00 digital pH meter. DO was measured using a sensefon 378 digital model. The physicochemical characteristics of the test water are presented in table 2 .

Acute toxicity test was conducted according to the Organization for Economic Cooperation and Development testing guidelines 202 guidelines (OECD, 2004). In the primary test, to quantify the NPs concentration, D. magna was exposed to $0.05,0.01,1.00,10.00$, 100.00 , and $200.00 \mathrm{mg} / \mathrm{l}$ in $96 \mathrm{~h}$ and the mortality was recorded in each treatment. In this stage, we used 15 individuals of $D$. magna in 0.5 litter beaker. This method was used for all three NPs. Then, totally $45 \mathrm{D}$. magna were exposed to different concentrations of the NPs for $24 \mathrm{~h}$, $48 \mathrm{~h}, 72 \mathrm{~h}$, and $96 \mathrm{~h}$. After that, based on mortality rate in the first stage, different concentration was made for each NP.

Based on the primary test, the concentrations of $\mathrm{ZnO}$ and $\mathrm{CuO}$ NPs were same as of 1, 3, 5, 7, 9, and $10 \mathrm{mg} / \mathrm{l}$. However, for $\mathrm{TiO}_{2} \mathrm{NPs}$, the test concentrations were 100, 120, 140, 160,180 , and $200 \mathrm{mg} / \mathrm{l}$. A control group was also set up without the test compound, using only fresh water. Exposures concentrations were carried out in triplicate groups in $500 \mathrm{ml}$ fresh water.

Slight aeration was provided through the bottom of beaker for $D$. magna, to prevent settling of NPs in the beaker. For all test groups, the light pattern was 16:8 h light: dark. All tests were conducted in the absence of food in all-time periods. D. magna was exposed to selected NPs for 24, 48, 72, and $96 \mathrm{~h}$. At the end of each period, live D. magna were counted.

The $\mathrm{LC}_{50}$ values (with $95 \%$ confidence) were calculated by the Probit Software (Zhu et al., 2008; Strigul et al., 2009; Ranjbar et al., 2011; Khoshnood et al., 2014). Significant differences between the control and all experimental samples were determined using the Bonferroni nonparametric post hoc tests, where $p<0.05$ was considered to be significantly different. SAR (Safe Application Rate) and SAFE (Safety Factor) coefficients were also calculated by $96 \mathrm{~h}$ acute toxicity test. The SAFE formula was used as indicated in Formula 1 (Basak and Konar, 1977; Jaafarzadeh et al., 2013).

Formula (1):

$$
\text { SAFE }=\frac{\mathrm{LC}_{0} \text { at } 96 \text { hours }}{\mathrm{LC}_{100} \text { at } 96 \text { hours }}
$$

$$
\text { Formula (2): } \quad \text { SAR }=\left(96 \text { hours } \mathrm{LC}_{50}\right) \times \mathrm{SAFE}
$$

Table 2: Physico-chemical properties of the test.

\begin{tabular}{|c|c|c|}
\hline Characteristics/Parameter & Range & Mean \pm SD \\
\hline Room Temperature & $27.8-29.1\left({ }^{\circ} \mathrm{C}\right)$ & $28.3 \pm 0.5$ \\
\hline Water Temperature & $22-22.3\left({ }^{\circ} \mathrm{C}\right)$ & $22.1 \pm 0.1$ \\
\hline Dissolved Oxygen & $6.9-7.2(\mathrm{mg} / \mathrm{l})$ & $7.2 \pm 0.12$ \\
\hline $\mathrm{pH}$ & $7-7.4$ & $7.1 \pm 0.1$ \\
\hline
\end{tabular}




\section{RESULTS}

No mortality was observed in the control group during the experiment. The toxicity of NPs to Daphnia magna was increased with increasing concentration of selected NPs and duration the exposure $(\mathrm{p}<0.05)$. Mortality percent of the $D$. magna in each test are presented in table 3.

Table 3: Mortality Percent (\%) of the D. magna after exposure to NPs.

\begin{tabular}{|c|c|c|c|c|c|}
\hline \multirow{3}{*}{ NPs } & Concentration & \multicolumn{4}{|c|}{ Time } \\
\cline { 2 - 6 } & & $24 \mathrm{~h}$ & $48 \mathrm{~h}$ & $72 \mathrm{~h}$ & $96 \mathrm{~h}$ \\
\hline \multirow{4}{*}{ ZnO } & Control & 0.0 & 0.0 & 0.0 & 0.0 \\
\cline { 2 - 6 } & 1 & 11.1 & 28.8 & 48.9 & 68.9 \\
\cline { 2 - 6 } & 3 & 26.7 & 42.3 & 71.1 & 95.6 \\
\cline { 2 - 6 } & 5 & 35.5 & 53.3 & 77.8 & 97.8 \\
\cline { 2 - 6 } & 7 & 48.9 & 64.4 & 86.7 & 100 \\
\cline { 2 - 6 } & 9 & 64.4 & 77.8 & 95.6 & 100 \\
\hline \multirow{4}{*}{$\mathrm{CuO}$} & 10 & 64.4 & 82.2 & 95.6 & 100 \\
\cline { 2 - 6 } & Control & 0.0 & 0.0 & 0.0 & 0.0 \\
\cline { 2 - 6 } & 1 & 11.1 & 13.3 & 17.8 & 26.7 \\
\cline { 2 - 6 } & 3 & 22.3 & 22.3 & 33.4 & 44.5 \\
\cline { 2 - 6 } & 5 & 33.4 & 37.8 & 46.6 & 55.5 \\
\cline { 2 - 6 } & 7 & 46.7 & 51.1 & 60.0 & 68.8 \\
\cline { 2 - 6 } & 10 & 55.6 & 60.0 & 66.7 & 82.2 \\
\hline \multirow{7}{*}{$\mathrm{TiO}_{2}$} & Control & 60.0 & 66.7 & 77.8 & 91.2 \\
\cline { 2 - 6 } & 100 & 6.0 & 0.0 & 0.0 & 0.0 \\
\cline { 2 - 6 } & 120 & 13.6 & 11.1 & 22.2 & 28.8 \\
\cline { 2 - 6 } & 140 & 17.7 & 26.0 & 33.3 & 42.3 \\
\cline { 2 - 6 } & 160 & 35.6 & 44.5 & 64.5 & 77.8 \\
\cline { 2 - 6 } & 180 & 46.6 & 55.5 & 73.3 & 93.3 \\
\cline { 2 - 6 } & 200 & 55.5 & 64.5 & 86.6 & 100 \\
\hline
\end{tabular}

The results of 57 acute toxicity tests (54 cases and three controls), performed with $\mathrm{TiO}_{2}, \mathrm{CuO}$, and $\mathrm{ZnO}$, expressed as $\mathrm{LC}_{10}, \mathrm{LC}_{50}$, and $\mathrm{LC}_{90}$ values, are summarized in table 4 and figures 1 to 3.

The controls showed no mortality in 24, 48, 72, and 96 h. As mentioned above, all the exposures tests were conducted in the absence of feeding. No mortalities in the control treatment could describe the fact that food lack did not induce any lethal effects on this species even up to $96 \mathrm{~h}$. In $24 \mathrm{~h}$, the average mortality ranged from $11.1 \%$ (one mg/l) to $64.4 \%$ (9, $10 \mathrm{mg} / \mathrm{l})$ for $\mathrm{ZnO} \mathrm{NPs}$, from $11.1 \%$ (one $\mathrm{mg} / \mathrm{l}$ ) to $60 \%$ (10 mg/l) for CuO NPs, and from $6.6 \%(100 \mathrm{mg} / \mathrm{l})$ to $55.5 \%$ (200 mg/l) for $\mathrm{TiO}_{2} \mathrm{NPs}$.

The average mortality in $96 \mathrm{~h}$ exposure was about $68.9 \%$ in one $\mathrm{mg} / \mathrm{l}$ suspensions of the $\mathrm{ZnO}$ NPs and increased to $100 \%$ in 7, 9, $10 \mathrm{mg} / \mathrm{l}$ suspensions. Likewise, the mortality rate of $\mathrm{CuO} \mathrm{NPs}$ was $26.7 \%$ in one $\mathrm{mg} / \mathrm{l}$ suspensions and increased to $91.2 \%$ in $10 \mathrm{mg} / \mathrm{l}$ suspensions. For $\mathrm{TiO}_{2}$ NPs, the average mortality was about $28.8 \%$ in $100 \mathrm{mg} / \mathrm{l}$ suspensions and increased to $100 \%$ in $200 \mathrm{mg} / \mathrm{l}$ suspensions. 
These results of mortality percent, point to the fact that both $\mathrm{TiO}_{2}$ and $\mathrm{CuO}$ NPs showed moderate toxicity to Daphnia magna at $96 \mathrm{~h}$ of exposure compared to $\mathrm{CuO}$ regardless of their size and concentration. The toxicity pattern in mortality percent of metal oxides to D. magna at $24 \mathrm{~h}$ of exposure was in the order of $\mathrm{ZnO}>\mathrm{CuO}>\mathrm{TiO}_{2}$.

In the present study, $\mathrm{CuO}$ NPs were found to have a $24 \mathrm{~h} \mathrm{LC} 50$ of $7.85 \mathrm{mg} / \mathrm{l}$, for $\mathrm{ZnO} \mathrm{LC}{ }_{50}$ at $24 \mathrm{~h}$ was found to be $6.58 \mathrm{mg} / \mathrm{l}$, and for $\mathrm{TiO}_{2}$ was $188.99 \mathrm{mg} / \mathrm{l}$ which was around 28 times higher than that of ZnO NPs and around 25 times higher than that of $\mathrm{CuO}$ NPs.

Formula 1 and 2 were used to calculate the safety factor of SAFE and SAR coefficients. For $\mathrm{CuO}$ NPs, SAFE and SAR were 0.001 and 0.002 , respectively. By considering the obtained value of SAR $(0.002 \mathrm{mg} / \mathrm{l})$, it could be seen that effluents with this SAR could enter the water body without any concerning about mortality in some sensitive organisms such as D. magna. SAFE and SAR values were 0.010 and 0.006 for ZnO NPs, respectively; showing it could not be very harmful at this level for some aquatic organisms such as D. magna. Table 5 shows SAFE and SAR values.

Table 4: The toxicity (mg/l) of NPs on D. magna.

\begin{tabular}{|c|c|c|c|c|}
\hline $\begin{array}{c}\text { Nano } \\
\text { Particles }\end{array}$ & Time & LC $_{10}$ & LC $_{50}$ & LC $_{90}$ \\
\hline \multirow{4}{*}{$\mathrm{CuO}$} & $24 \mathrm{~h}$ & 1.16 & 7.85 & 53.23 \\
\cline { 2 - 5 } & $48 \mathrm{~h}$ & 1.06 & 6.62 & 41.32 \\
\cline { 2 - 5 } & $72 \mathrm{~h}$ & 0.74 & 4.66 & 29.30 \\
\cline { 2 - 5 } & $96 \mathrm{~h}$ & 0.53 & 2.99 & 16.74 \\
\hline \multirow{4}{*}{$\mathrm{ZnO}$} & $24 \mathrm{~h}$ & 1.12 & 6.58 & 38.66 \\
\cline { 2 - 5 } & $48 \mathrm{~h}$ & 0.40 & 3.23 & 25.99 \\
\cline { 2 - 5 } & $72 \mathrm{~h}$ & 0.28 & 1.19 & 7.71 \\
\cline { 2 - 5 } & $96 \mathrm{~h}$ & 0.20 & 0.64 & 2.05 \\
\hline \multirow{4}{*}{$\mathrm{TiO}_{2}$} & $24 \mathrm{~h}$ & 113.18 & 188.99 & 294.35 \\
\cline { 2 - 5 } & $48 \mathrm{~h}$ & 100.36 & 171.88 & 225.91 \\
\cline { 2 - 5 } & $72 \mathrm{~h}$ & 85.69 & 139.14 & 176.30 \\
\cline { 2 - 5 } & $96 \mathrm{~h}$ & 76.92 & 123.79 & \\
\hline
\end{tabular}

Table 5: SAFE and SAR Coefficient's values.

\begin{tabular}{|c|c|c|}
\hline Nano Particles & SAFE & SAR \\
\hline $\mathrm{CuO}$ & 0.001 & 0.002 \\
\hline $\mathrm{ZnO}$ & 0.010 & 0.006 \\
\hline $\mathrm{TiO}_{2}$ & 0.270 & 33.420 \\
\hline
\end{tabular}




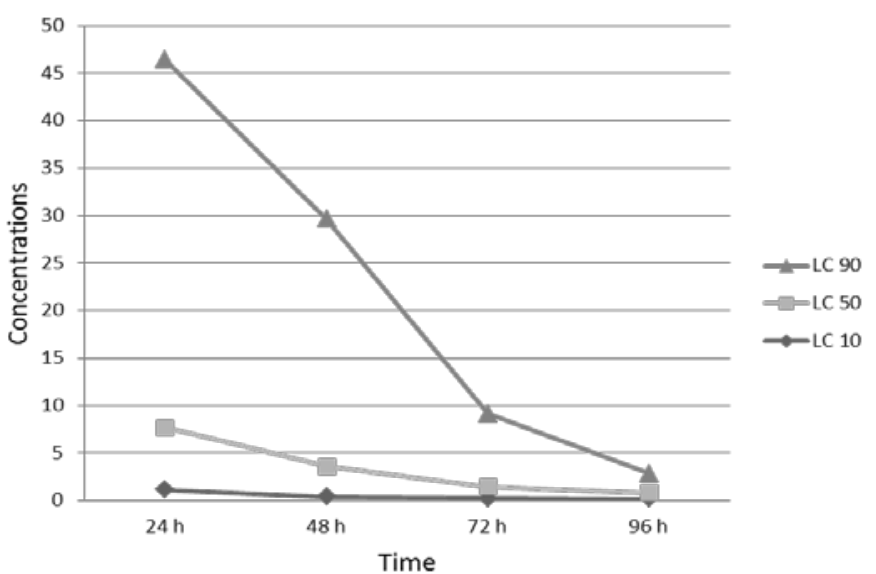

Figure 1: Acute toxicity (mg/l) of ZnO NPs in Daphnia magna.

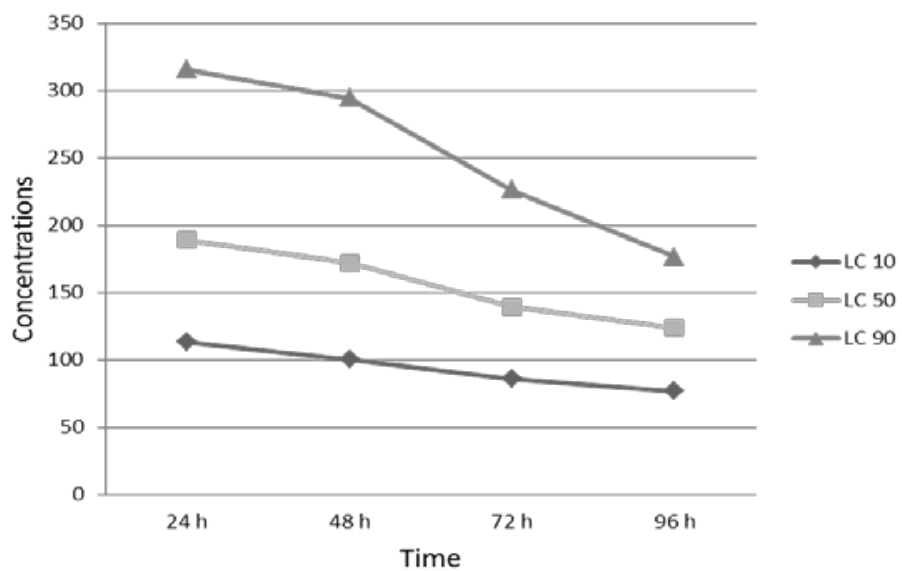

Figure 2: Acute toxicity (mg/l) of $\mathrm{TiO}_{2}$ NPs in Daphnia magna.

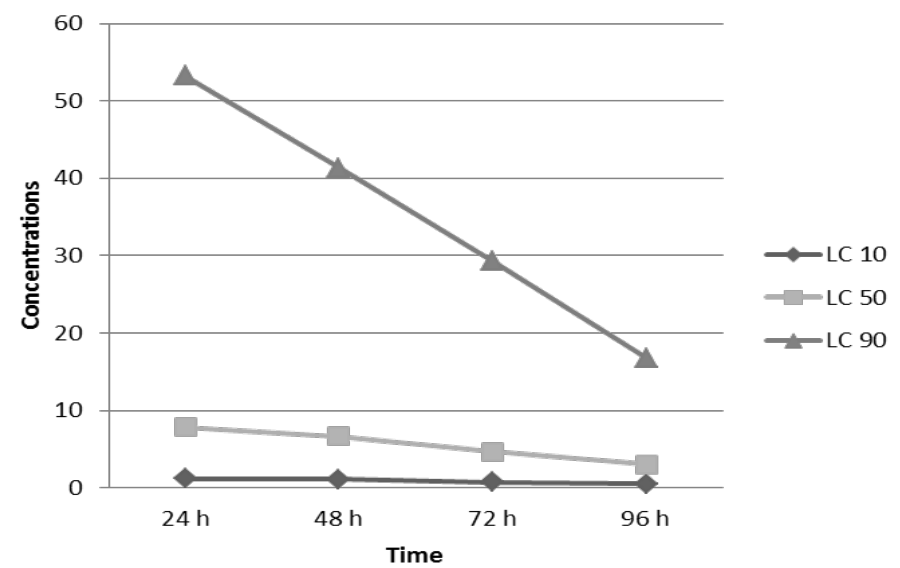

Figure 3: Acute toxicity (mg/l) of CuO NPs in Daphnia magna. 
Table 6 shows the results of some other studies about the toxicity of NPs on D. magna which can be used to compare with our findings. In the present study, the $\mathrm{LC}_{50}$ value for the acute toxicity tests of ZnO NPs on D. magna at $48 \mathrm{~h}$ was $3.23 \mathrm{mg} / \mathrm{l}$. For the same species, Heinlaan reported a $48 \mathrm{~h} \mathrm{LC}_{50}$ acute toxicity value of $3.20 \mathrm{mg} / \mathrm{l}$ for the acute toxicity of $\mathrm{Zn}$ (Heinlaan et al., 2008), which is close to the $\mathrm{LC}_{50}$ values obtained in the present study. On the other hand, Liu et al. (2014) reported toxicity value for $48 \mathrm{~h} \mathrm{LC}_{50}$ as $6.32 \mathrm{mg} / \mathrm{l}$, that are two times more than the results of this study and those obtained by Heinlaan et al. (2008). Also, Zhu et al. (2008), Wiench et al. (2009), and Lopes et al. (2014) found $48 \mathrm{~h} \mathrm{LC}_{50}$ value of 1.511 $\mathrm{mg} / \mathrm{l}$, one $\mathrm{mg} / \mathrm{l}$, and $1.10 \mathrm{mg} / \mathrm{l}$ respectively, which are about three times lower than the present results.

About $\mathrm{TiO}_{2}$, the $48 \mathrm{~h} \mathrm{LC} 50$ of $D$. magna was $171.877 \mathrm{mg} / \mathrm{l}$. In addition, Zhu et al. (2008) (Zhu et al., 2008) reported this value as of $143.387 \mathrm{mg} / \mathrm{l}$ which is close to the results of the present study.

For CuO NPs, the calculated $48 \mathrm{~h} \mathrm{LC}_{50}$ was $6.624 \mathrm{mg} / \mathrm{l}$ in the present study, however Luiet al. (2014) and Heinlaan et al. (2008) reported this value as $5.56 \mathrm{mg} / \mathrm{l}$ and $3.2 \mathrm{mg} / \mathrm{l}$, respectively (Liu et al., 2014; Heinlaan et al., 2008).

Based on our results, any difference between toxicity thresholds may be related to the particle size differences, analyzing and preparation methods, or test designs and inconsistent test conditions such as $\mathrm{pH}$, photoperiod, and dissolved oxygen (DO) (Wang et al., 2016). For example, the diameter of the $\mathrm{TiO}_{2}$ used in $\mathrm{Zhu}$ et al. (2008) study was $20 \mathrm{~nm}$, but in the present study, it was $10-30 \mathrm{~nm}$, and about other NPs, the actual size of the $\mathrm{TiO}_{2}$ NPs in this study was $20 \mathrm{~nm}$ and in Heinlaan study was $50-70 \mathrm{~nm}$. The toxicity of metal oxide NPs may be partially due to the release of metal ions. Blinova et al. (2010) reported that the toxicity of $n \mathrm{CuO}($ nano $\mathrm{CuO}$ ) and $n \mathrm{ZnO}($ nano $\mathrm{ZnO}$ ) in natural waters resulted mainly from dissolved metal ions (Blinova et al., 2010).

In some cases, NPs were observed in the Daphnia intestine. Aquatic animals such as D. magna may consume or eat NPs, mistaking them for food. In this situation, NPs agglomerate further in the digestive system, and finally block it and cause death (Strigul et al., 2009; Wiench et al., 2009).

Cytotoxicity of metal oxide NPs to mammalian cells is strongly influenced by the dissolution of those NPs (Brunner et al., 2006). However, Baek et al. (2011) reported the toxicity of four metal oxide NPs and found that the toxicity induced by the dissolved ions was negligible (Baek and An, 2011). The toxicity mechanism of metal oxide NPs is very complex and has not been completely defined (Hai-zhou et al., 2012). 
Table 6: Comparing acute toxicity test of nanoparticles on D. magna.

\begin{tabular}{|c|c|c|c|c|c|c|}
\hline & & & $\begin{array}{l}\mathrm{ZNO} \\
\left(\mathrm{ML}^{-1}\right)\end{array}$ & $\begin{array}{l}\mathrm{TIO}_{2} \\
\left(\mathrm{ML}^{-1}\right)\end{array}$ & $\begin{array}{l}\text { CUO } \\
\left(\mathrm{ML}^{-1}\right)\end{array}$ & \\
\hline $\begin{array}{c}D . \\
\text { magna }\end{array}$ & $\begin{array}{l}\text { Acute toxicity } \\
\text { Nano size and } \\
\text { bulk }\end{array}$ & $\mathrm{TiO}_{2}, \mathrm{CuO}, \mathrm{TiO}_{2}$ & 3.2 & $\begin{array}{l}\text { LC > } \\
2000\end{array}$ & 3.2 & $\begin{array}{l}\text { (Heinlaan } \\
\text { et al., } \\
\text { 2008) }\end{array}$ \\
\hline $\begin{array}{c}D . \\
\text { magna }\end{array}$ & Acute toxicity & $\begin{array}{c}\mathrm{ZnO}, \mathrm{TiO}_{2}, \mathrm{Al}_{2} \mathrm{O}_{3}, \\
\mathrm{C}^{60}, \text { SWCNTs }^{*}, \\
\text { MWCNTs }\end{array}$ & 1.511 & 143.387 & - & $\begin{array}{c}\text { (Zhu et } \\
\text { al., 2008) }\end{array}$ \\
\hline $\begin{array}{c}D . \\
\text { magna }\end{array}$ & $\begin{array}{l}\text { Acute } \\
\text { toxicity, } \\
\text { chronic } \\
\text { toxicity, } \\
\text { mobility, } \\
\text { reproduction }\end{array}$ & $\begin{array}{c}\mathrm{TiO}_{2}, \mathrm{ZnO} \\
\text { (Nano and non-Nano) }\end{array}$ & 1 & $\begin{array}{c}\mathrm{LC}> \\
50\end{array}$ & - & $\begin{array}{l}\text { (Wiench } \\
\text { et al., } \\
\text { 2009) }\end{array}$ \\
\hline $\begin{array}{c}D . \\
\text { magna }\end{array}$ & Acute toxicity & $\mathrm{TiO}_{2}, \mathrm{Al}, \mathrm{B}$ & - & $\begin{array}{c}\mathrm{LC}> \\
250\end{array}$ & - & $\begin{array}{l}\text { (Strigul } \\
\text { et al., } \\
\text { 2009) }\end{array}$ \\
\hline $\begin{array}{c}D . \\
\text { magna }\end{array}$ & $\begin{array}{c}\text { Acute } \\
\text { toxicity, } \\
\text { chronic } \\
\text { toxicity, NPs } \\
\text { size, mobility }\end{array}$ & $\mathrm{ZnO}$ & 1.10 & - & - & $\begin{array}{l}\text { (Lopes } \\
\text { et al., } \\
2014 \text { ) }\end{array}$ \\
\hline $\begin{array}{c}D . \\
\text { magna }\end{array}$ & $\begin{array}{c}\text { Acute } \\
\text { toxicity, Size }\end{array}$ & $\mathrm{ZnO}, \mathrm{CuO}, \mathrm{Au}, \mathrm{TiO}_{2}$ & 6.73 & - & 5.66 & $\begin{array}{l}\text { (Liu } \\
\text { et al., } \\
2014 \text { ) }\end{array}$ \\
\hline $\begin{array}{c}D . \\
\text { magna }\end{array}$ & $\begin{array}{c}\text { Acute } \\
\text { toxicity, Size }\end{array}$ & $\mathrm{TiO}_{2}$ & - & $\begin{array}{c}\mathrm{LC}> \\
100\end{array}$ & - & $\begin{array}{l}\text { (Johari } \\
\text { and } \\
\text { Asghari } \\
\text { 2015) }\end{array}$ \\
\hline $\begin{array}{c}D . \\
\text { magna }\end{array}$ & $\begin{array}{c}\text { Chronic } \\
\text { exposure }\end{array}$ & $\mathrm{CuO}, \mathrm{CuCl}_{2},{ }_{2} \mathrm{H}_{2} \mathrm{O}$ & - & - & 1.041 & $\begin{array}{l}\text { (Adam } \\
\text { et al., } \\
2015) \\
\end{array}$ \\
\hline $\begin{array}{c}D . \\
\text { magna }\end{array}$ & Acute toxicity & $\mathrm{TiO}_{2}, \mathrm{CuO}, \mathrm{TiO}_{2}$ & 3.232 & 171.877 & 6.624 & $\begin{array}{l}\text { This } \\
\text { study }\end{array}$ \\
\hline
\end{tabular}

* Single-walled carbon nanotube

** Multiple-walled carbon nanotube 


\section{CONCLUSIONS}

The results of this study showed that $\mathrm{LC}_{50} 96 \mathrm{~h} \mathrm{TiO}$ nanoparticles were much less toxic to D. magna than $\mathrm{CuO}$ and $\mathrm{ZnO}$ NPs. Based on our results in this study, it can be concluded that:

- The selected NPs in the present study $\left(\mathrm{CuO}, \mathrm{ZnO}\right.$, and $\left.\mathrm{TiO}_{2}\right)$ may have acute dosedependent eco-toxicological effects on $D$. magna.

- NPs with different compositions or different size show different toxicities effects on aquatic organisms.

- NPs toxicity effect could be as a result of the NPs properties, dissolution methods, and NPs agglomerates which were developed during the test.

- The results of this study indicated that the potential eco-toxicity and environmental health effects of NPs should be given due attention.

\section{ACKNOWLEDGEMENTS}

The authors are grateful to Dr. Zareie and Mrs. Moebed and other KWPA Central Laboratory staff for their valuable assistance in laboratory experiments and especial thanks due to the staff of all laboratories who participated in the inter-laboratory test and data generation.

\section{REFERENCES}

1. Adam N., Alexander V., Dries K. and Ronny B., 2015 - The chronic toxicity of $\mathrm{CuO}$ nanoparticles and copper salt to Daphnia magna, Journal of Hazardous Materials, 283, 416-422, doi: http://dx.doi.org/10.1016/j.jhazmat.2014.09.037.

2. Ates M., Daniels J., Arslan Z. and Farah I. O., 2013 - Effects of aqueous suspensions of titanium dioxide nanoparticles on Artemia salina: assessment of nanoparticle aggregation, accumulation, and toxicity, Environmental Monitoring Assessessment, 185, 4, 3339-48, doi: 10.1007/s10661-012-2794-7.

3. Baek Y. W. and An Y. J., 2011 - Microbial toxicity of metal oxide nanoparticles $(\mathrm{CuO}, \mathrm{NiO}$, $\mathrm{ZnO}$ and $\mathrm{Sb}_{2} \mathrm{O}_{3}$ ) to Escherichia coli, Bacillus subtilis, and Streptococcus aureus, Science of The Total Environment, 409, 8, 1603-8, doi: 10.1016/j.scitotenv.2011.01.014.

4. Basak P. K. and Konar S. K., 1977 - Estimation of Safe Concentration of Insecticides A New Method Tested on DDT and BHC, Journal of Inland Fisher Society, 9, 19-29.

5. Blinova I., Ivask A., Heinlaan M., Mortimer M. and Kahru A., 2010 - Ecotoxicity of nanoparticles of $\mathrm{CuO}$ and $\mathrm{ZnO}$ in natural water, Environmental Pollution, 158, 1, 41-7, doi: 10.1016/j.envpol.2009.08.017.

6. Brunner T. J., Wick P., Manser P., Spohn P., Grass R. N., Limbach L. K., Bruinink A. and Stark W. J., 2006 - In vitro cytotoxicity of oxide nanoparticles: comparison to asbestos, silica, and the effect of particle solubility, Environmental Science and Technology, 40, 14, 4374-81.

7. Fabrega J., Luoma S. N., Tyler C. R., Galloway T. S. and Lead J. R., 2013 - Silver nanoparticles: behaviour and effects in the aquatic environment, Environmental International, 37, 2, 517-31, doi: 10.1016/j.envint.2010.10.012.

8. Griffitt R. J., Luo J., Gao J., Bonzongo J. C. and Barber D. S., 2008 - Effects of particle composition and species on toxicity of metallic nanomaterials in aquatic organisms, Environmental Toxicology and Chemistry, 27, 9, 1972-8, doi: 10.1897/08-002.1.

9. Hai Z., Zhao Z., Lu G. H., Xia J. and Jin S., 2012 - Toxicity of nanoscale CuO and ZnO to Daphnia magna, Chemical Research in Chinese Universities, 28, 2, 209-213.

10. Heinlaan M., Angela I., Irina B., Henri-Charles D. and Anne K., 2008 - Toxicity of nanosized and bulk $\mathrm{ZnO}, \mathrm{CuO}$ and $\mathrm{TiO}_{2}$ to bacteria Vibrio fischeri and crustaceans Daphnia magna and Thamnocephalus platyurus, Chemosphere, 71, 7, 1308-1316, doi: http://dx.doi.org/10.1016/j.chemosphere.2007.1.047. 
11. Jaafarzadeh N., Hashempour Y. and Ahmadi Angali K., 2013 - Acute toxicity test using cyanide on Daphnia magna by flow-through system, Journal of Water Chemistry and Technology, 35, 6, 281-286, doi: 10.3103/s1063455x13060076.

12. Johari S. A. and Asghari S., 2015 - Acute toxicity of titanium dioxide nanoparticles in Daphnia magna and Pontogammarus maeoticus, Journal of Advances in Environmental Health Research, 3, 2, 111-119.

13. Khoshnood Z., Jamili S., Khodabandeh S., Mashinchian Moradi A. and Motallebi Moghanjoghi A. A., 2014 - Histopathological effects and toxicity of atrazine herbicide in Caspian Kutum, Rutilus frisii kutum, fry, Iranian Journal of Fisheries Sciences, 13, 3, 702-718.

14. Liu J., Deling F., Lei W., Lili S., Jie D., Yingwen C. and Shubao S., 2014 - Effects of Zno, Cuo, $\mathrm{Au}$, and $\mathrm{Tio}_{2}$ Nanoparticles on Daphnia magna And Early Life Stages Of Zebrafish Danio rerio, Environment Protection Engineering, 40, 1, 139-149, doi: 10.5277/epe140111.

15. Lopes S., Ribeiro F., Wojnarowicz J., Lojkowski W., Jurkschat K., Crossley A., Soares A. M. and Loureiro S., 2014 - Zinc oxide nanoparticles toxicity to Daphnia magna: size-dependent effects and dissolution, Environmental Toxicology and Chemistry, 33, 1, 190-8, doi: 10.1002/etc.2413.

16. Lovern S. B. and Klaper R., 2006 - Daphnia magna mortality when exposed to titanium dioxide and fullerene $\left(\mathrm{C}^{60}\right)$, Environmental Toxicology and Chemistry, 25, 4, 1132-7.

17. Masciangioli T. and Wei-Xian Z., 2003 - Peer Reviewed: Environmental Technologies at the Nanoscale, Environmental Science and Technology, 37, 5, 102A-108A, doi: 10.1021/es0323998.

18. McMahon J. W. and Rigler F. H., 1965 - Feeding Rate of Daphnia Magna Straus in Different Foods Labeled with Radioactive Phosphorus, Limnology and Oceanography, 10, 1, 105-113, doi: 10.4319/lo.1965.10.1.0105.

19. OECD., 2004 - Guideline for the testing of chemicals, Organisation for Economic Co-operation and Development (OECD).

20. Ozkan Y., Ilhan A., Hasan I. and Munever S., 2015 - Determination of $\mathrm{TiO}_{2}$ and $\mathrm{AgTiO}_{2}$ Nanoparticles in Artemia salina: Toxicity, Morphological Changes, Uptake and Depuration, Bulletin of Environmental Contamination and Toxicology, 96, 1, 36-42, doi: 10.1007/s00128015-1634-1.

21. Ranjbar M., JaafarZadeh N., Piri M. and Khodadady M., 2011 - Short communication-Survey of Methyl Tertiary Butyl Ether (MTBE) toxicity using bioassay on Daphnia magna, Iranian Journal of Fishery Science, 10, 3, 541-545.

22. Strigul N., Liana V., Catherine G., Mahmoud W., Xuyang L., Christos C. and Kristin J., 2009 - Acute toxicity of boron, titanium dioxide, and aluminium nanoparticles to Daphnia magna and Vibrio fischeri, Desalination, 248, 1-3, 771-782, doi: http://dx.doi.org/10.1016/j.desal.2009.01.013.

23. Wang D., Zhifen L., Ting W., Zhifeng Y., Mengnan Q., Shourong Z. and Wei L., 2016 Where does the toxicity of metal oxide nanoparticles come from: The nanoparticles, the ions, or a combination of both? Journal of Hazardous Materials, 308, 328-334, doi: http://dx.doi.org/10.1016/j.jhazmat.2016.01.066.

24. Wiench K., Wendel W., Volker H., Kristin R., Edward S., Sabine Z. and Robert L., 2009 Acute and chronic effects of nano- and non-nano-scale $\mathrm{TiO}_{2}$ and $\mathrm{ZnO}$ particles on mobility and reproduction of the freshwater invertebrate Daphnia magna, Chemosphere, 76, 10, 1356-1365, doi: http://dx.doi.org/10.1016/j.chemosphere.2009.06.025.

25. Zhu X., Chang Y. and Chen Y., 2010 - Toxicity and bioaccumulation of $\mathrm{TiO}_{2}$ nanoparticle aggregates in Daphnia magna, Chemosphere, 78, 3, 209-15, doi: 10.1016/j.chemosphere.2009.11.013.

26. Zhu X., Lin Z., Yongsheng C. and Shengyan T., 2008 - Acute toxicities of six manufactured nanomaterial suspensions to Daphnia magna, Journal of Nanoparticle Research, 11, 1, 67-75, doi: 10.1007/s11051-008-9426-8. 